\title{
Marketing orientation as a basis for retail structures' innovative development
}

\author{
Yulia Medvedeva ${ }^{1, *}$ \\ ${ }^{1}$ Don State Technical University, 344000, Rostov-on-Don, Russia
}

\begin{abstract}
Transformation of trade processes together with a system approach is the prerequisite for research of marketing management of innovative development of trade enterprises. The development of theoretical and conceptual provisions of marketing management of retail structures' (RS) innovative development is based on the study of the evolution of marketing concepts in conjunction with the genesis of retail trade, based on the change of technological structures. The transformation of retail trade development guidelines is determined, depending on changes in the subjects of influence. The most relevant concepts for innovative development are relationship marketing, co-creation marketing, customer experience marketing, and sustainable marketing. An integrated concept of marketing management of RS innovative development is proposed, the task of which is to provide catalyzing market innovation on the one hand and the resulting support for the commercialization of innovations. Based on the study of hierarchical relationships of marketing concepts in trade, features of innovative development of trade, the article defines the multiparadigm of modern marketing in trade, which allows us to form the concept of marketing management of RS innovative development. Its content means the implementation of a customer-oriented and customerinvolved retail enterprise management doctrine and is a process designed and managed by marketing, aimed at transforming technologies, methods, forms, and formats of trade
\end{abstract}

\section{Introduction}

The competitive landscape in the retail market is transforming. The strong competitive position built by the size and experience of the retailer is becoming unstable. The development of digital sales technologies and the transformation of consumer preferences result in changing approaches to trading business organization [1]. In the context of innovative development of the economy, the task of increasing the competitiveness of trade enterprises can be effectively solved through the implementation of innovative development.

Trade has distinctive features of innovative development. There is a high degree of dependence of innovative processes on the level of innovative development in related industries, including the manufacturing sector. Trade enterprises act as a conductor of

\footnotetext{
*Corresponding author: jjmedvet@yandex.ru
} 
goods from the manufacturer to the end consumer, and the assortment policy of a trade enterprise is based on a balance of interests of consumers and producers. The latter, in turn, strive to gain a competitive advantage in the new economy, including through the release of an innovative product. In trade, three types of processes can be implemented: trade (trade services), technological (movement of goods in the sphere of circulation) and production (making our own products), each of which being characterized by specific types of innovations.

Marketing management is focused on meeting the needs and demands of customers, supported by integrated marketing efforts aimed at creating customer satisfaction as the key to meeting organizational goals.

The opinions of practitioners and researchers in the field of retail development such as P. Verhoef, K. Lemon, A. Parasuraman (2009), J. Nordfält et al. (2014), A. L. Roggeveen et al. (2015), D. Grewal et al. (2017) are based on the postulate of a clearly expressed marketing orientation of the RS innovative processes.

\section{Materials and methods}

The research was carried out on a currently important matter. Marketing-oriented enterprise management issues have been relevant over the past three decades. The positive relationship between the level of a company's marketing orientation and the positive effect of innovation has been explored by such scholars as A. Kohli \& B. Jaworski (1990), W. Baker \& J. Sinkula (1999), R. Hurley \& T. Hult (1998), N. Lado \& A. Maydeu-Olivares (2001). However, research devoted to marketing management of RS innovative development is not enough.

O. S. Kompaniets (2011) proves that the marketing orientation of management is becoming a promising strategy for the development of trade enterprises, ensuring the unity of current strategic priorities, requirements for management bodies, actively using modern means of communication and forming a system of innovations.

The change in the role of trade, on the one hand, and the development of the concept of marketing orientation, on the other, determine the vector of retail trade innovative development in the field of marketing management, according to I. A. Krasyuk, I. V. Kapustina, S. G. Bozhuk, S. M. Krymov, M. V. Kolgan, T. A. Pereverzeva, O. E. Pirogova et al. $[11,12,13,14,15,16]$. Since innovation processes in trade have a clear consumer orientation, and marketing management is able to provide search and justification for changes and innovations as well as to prepare the market for innovation, the author believes that marketing management for retail can be considered a form of RS innovative development.

The objective of the research is to determine the main elements of the concept of marketing management of RS innovative development on the basis of logical, monographic and foresight research, methods of comparison, synthesis and structural analysis

\section{Results}

The essence of marketing management as a process of consistently performed management operations based on analysis, planning, determining ways to implement plans and monitoring key indicators, covers crucial areas of a transforming market economy. The main purpose and essence of marketing as a type of activity is the maintenance of relations associated with the exchange. B. Reformat (2016) connects the innovative development of society with the provision of new organizational and economic exchange relations. At the same time, innovations in the field of information technology, changes in consumer 
behaviour and the needs of society as a whole develop marketing and its tools. Information and communication technologies are a source of marketing innovations in retail.

The most obvious distinguishing feature of the marketing concept is the importance given to the consumer. All marketing activities, such as identifying needs, developing appropriate products and pricing, distributing and promoting them, must be consumeroriented.

The integrated management action of marketing is due to the fact that various functional areas of management are combined by the marketing function. Integrated marketing involves the correct interaction between different areas of management, with marketing influencing the corporate decision-making process [18].

The aim of the company, by adopting the marketing concept, is to satisfy the needs of its clients so perfectly that they become regular or permanent satisfied customers.

Assuming that organizational goals may differ from one company to another, we note that key areas such as innovation, market position, profit and social responsibility are common to all companies. According to the marketing concept, the best way to achieve these organizational goals is through customer satisfaction.

The concept of innovation is more often applied in the inductrial sphere, but it is not necessarily something tangible. The idea of selling by installments (on credit), the implementation of which literally changes the structure and volumes of consumption as well as the economy itself, surpasses many technical innovations in significance. In this case, the innovation for the trade organization can be viewed as a new value acquired by the consumer, meeting their needs and desires.

Scientific and technological progress also influenced trade, which led to additional mechanization and automation of the most labour-intensive operations of the trade and technological process and to improved organization of labour and management of technological processes.

Consequently, trade innovation can be understood as the purposeful implementation of technical, economic, social, legal and organizational changes in trade activities and consumer behaviour in order to obtain profit or other benefits (for example, increased competitiveness, increased market share, etc.).

Implementation of innovations provides retailers not only with additional profit by reducing distribution costs, improving the quality of trade services, but also allows increasing the competitiveness of trading companies, separating them from competitors and increasing customer loyalty.

\section{Discussion}

In a general sense, the innovative development of an enterprise is understood as a sequential process of purposeful movement of an enterprise to a balanced innovative state, characterized by a quality result achieved depending on the intensity and speed of innovative processes at the enterprise. Trade innovation tends to be continuous, representing a stepwise process. The main factors determining the innovative development of retail are as follows: business consolidation, the level of innovative development in the country and in the world, the competitive situation, the state of the investment climate, institutional and legislative regulation, and the culture of consumption [19].

Marketing management of RS innovative development is an organizational and managerial impact on the components of the trade and technological system, which determines the internal environment of an organization, and is aimed at increasing the level of adaptability, operational maneuverability of retail enterprises in the formation of relationships with consumers and other stakeholders. 
The evolution of marketing concepts in trade coincides with the general trend of personification and consumer engagement in value creation [20]. Some manufacturers and retailers are moving away from mass production, giving consumers the ability to customize their own unique products. [21] Customization as a basic vector to develop the economy as a whole and specific acreas of trade is an effective tool for gaining a competitive advantage based on marketing, organizational and information innovations (Table 1)

Table 1. The evolution of marketing concepts in trade in conjunction with the stages of retail trade development (compiled by the author based on the research by V. V. Panyukova (2017) and O. U.

Yuldasheva (2018).

\begin{tabular}{|c|c|c|c|c|}
\hline Name & $\begin{array}{l}\text { Subject of } \\
\text { influence }\end{array}$ & $\begin{array}{l}\text { Characteristics } \\
\text { of the retail } \\
\text { development }\end{array}$ & $\begin{array}{c}\begin{array}{c}\text { Orientation } \\
\text { of marketing } \\
\text { activities / } \\
\text { Buyer type / } \\
\text { Marketing } \\
\text { concept }\end{array} \\
\end{array}$ & $\begin{array}{l}\text { Features of the } \\
\text { marketing concept of a } \\
\text { trade enterprise }\end{array}$ \\
\hline $\begin{array}{l}\text { Retail } 1.0 \\
\text { The birth } \\
\text { of modern } \\
\text { retail } \\
(1900- \\
1960) \\
\end{array}$ & $\begin{array}{l}\text { The main } \\
\text { influence is } \\
\text { exerted by the } \\
\text { manufacturer }\end{array}$ & $\begin{array}{l}\text { Mainly consists } \\
\text { of stationary } \\
\text { retail outlets }\end{array}$ & $\begin{array}{l}\text { Price / } \\
\text { Passive buyer/ } \\
\text { Manufacturing } \\
\text { improvements }\end{array}$ & $\begin{array}{l}\text { Differentiation of trade } \\
\text { enterprises through } \\
\text { pricing policy }\end{array}$ \\
\hline $\begin{array}{l}\text { Retail } 2.0 \\
\text { The era of } \\
\text { large-scale } \\
\text { trading } \\
(1960- \\
1994)\end{array}$ & $\begin{array}{l}\text { Shifting } \\
\text { emphasis of } \\
\text { influence: } \\
\text { from suppliers } \\
\text { to retail }\end{array}$ & $\begin{array}{l}\text { Mainly consists } \\
\text { of stationary } \\
\text { retail facilities, } \\
\text { there is a } \\
\text { constant } \\
\text { increase in the } \\
\text { number of } \\
\text { network } \\
\text { facilities }\end{array}$ & $\begin{array}{l}\text { Product/ } \\
\text { Passive buyer/ } \\
\text { Product } \\
\text { improvements } \\
\text { traditional } \\
\text { marketing }\end{array}$ & $\begin{array}{l}\text { Differentiation of trade } \\
\text { enterprises through } \\
\text { specialization, breadth of } \\
\text { assortment and } \\
\text { promotions }\end{array}$ \\
\hline $\begin{array}{l}\text { Retail } 3.0 \\
\text { The era of } \\
\text { e- } \\
\text { commerce } \\
(1995- \\
\text { early } \\
2000 \text { s of } \\
\text { the } 21 \text { st } \\
\text { century) }\end{array}$ & Retail dictate & $\begin{array}{l}\text { Growth in the } \\
\text { number of chain } \\
\text { shopping } \\
\text { facilities, } \\
\text { including } \\
\text { modern formats, } \\
\text { multi-format } \\
\text { and } \\
\text { development of } \\
\text { online stores }\end{array}$ & $\begin{array}{c}\text { Service / } \\
\text { Co-creator f value / } \\
\text { Relationship } \\
\text { marketing } \\
\text { Engagement } \\
\text { marketing } \\
\text { Co-creation of } \\
\text { values }\end{array}$ & $\begin{array}{l}\text { Differentiation of trade } \\
\text { enterprises occurs } \\
\text { through the provision of } \\
\text { a differentiated set of } \\
\text { services that provide a } \\
\text { value proposition in } \\
\text { accordance with the } \\
\text { trading format. Sellers } \\
\text { select goods to offer to } \\
\text { the buyer, influencing } \\
\text { the product } \\
\text { manufacturers through } \\
\text { the establishment of } \\
\text { individual conditions for } \\
\text { themselves. }\end{array}$ \\
\hline
\end{tabular}




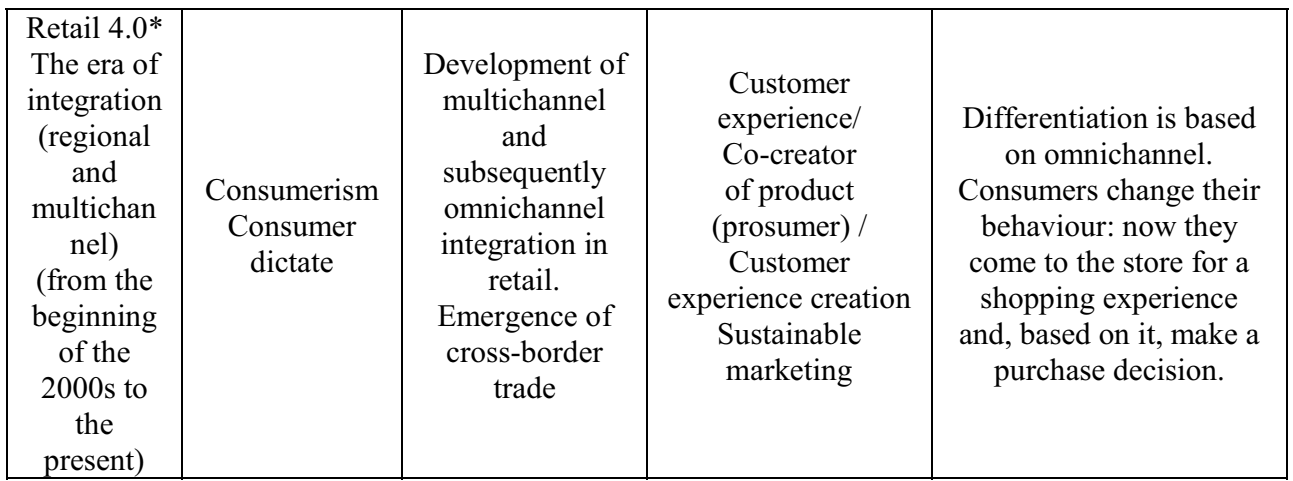

* Retail 4.0 is a concept for organizing trading activities based on the use of a combination of technologies, data, analytics, digital media, mobile devices, automation, cloud computing and artificial intelligence [21].

As presented in Table 1, transformation of retail trade development benchmarks depends on changes in the subjects of influence on the basis of evolutionary analysis of retail marketing concepts in conjunction with the stages of retail trade development. Thus, such a transformation makes it possible to substantiate an integrated concept of marketing management of RS innovative development, the task of which is to catalyze the RS market innovation and to provide the resulting accompaniment to the commercialization of innovations.

J. J. Inman and H. Nikolova (2017) and D. Grewal et al. (2017) note that the new economic conditions predetermine the creation of a new form of retail trade which is based on digital technologies, focused on a specific buyer and formed with their participation, taking into account their proposals, and operates in a resource-saving and partnershipbuilding environment.

The concept of marketing management of innovative development of trade enterprises implies the following:

- determining market needs for new products, improvement or modernization of existing ones, thus meeting the needs of manufacturers in providing infrastructure to develop innovations;

- searching for new ways to maximize customer satisfaction through the use of instrumental and methodological marketing apparatus and ensuring innovative development based on new opportunities to meet customer needs [24, 25];

- increasing the efficiency of trading activities by transforming traditional distribution channels, implementing new ways to achieve market influence through integration, cooperation, and cost optimization.

The marketing nature of management is treated as strategic organizational behaviour that focuses on responding to customer needs and market conditions through the generation and dissemination of market knowledge within a company. Since innovation processes in trade have a clear consumer orientation, and marketing management is able to provide search and justification for changes and innovations as well as to prepare the market for innovation, the author believes that marketing management for retail can be considered a form of RS innovative development. The subject of marketing management of innovative development include RS, consumers, manufacturers (or brand owners). The object of marketing management is what the marketing efforts of the subject of management are directed to: technological process, trade process, competitive environment, consumer satisfaction, innovative environment, which together determine the value of a trade service 


\section{Conclusion}

Determining the impact of marketing on the success of trade enterprises, it can be stated that marketing is a profit-generating factor of commercial activity. The competitive motive behind the trade transformation is the consumer.

Analysis of the trends and determinants of the innovative development of retail trade and the resources available for this has determined that the material and technical resources possessed by retail structures are significantly inferior to the industrial sphere. At the same time, retail trade is inherently adaptable and demonstrates innovative activity. The specificity of the theory and methodology of marketing management in trade, presented in modern research papers, is based on the provisions of service marketing, trade marketing and strategic marketing.

The concept of marketing in trade as a system of basic views, provisions and tools of the company's activities, which allow to more effectively meet the needs of the end consumer and, thereby, optimally and quickly achieve the company's goals, determines the approaches to the innovative development of a trade enterprise.

Hierarchical interconnections of marketing concepts in trade and features of innovative development of trade establish the multi-paradigm of modern marketing in trade and also allow to form the concept of marketing management of innovative development of retail. Its content means the implementation of a customer-oriented and customer engagement doctrine of retail trade enterprise management and is a process designed and managed by marketing, aimed at transforming technologies, methods, forms and formats of trade.

\section{References}

1. V.A. Bondarenko, A.A. Voronov, A.A. Maksaev, N.V. Poluyanova, International Journal of Economics \& Business Administration 8(1), 24-32 (2020)

2. P. Verhoef, K. Lemon, A. Parasuraman, A. Roggeveen, M. Tsiros, L. Schlesinger, Journal of Retailing 85(1), 31-41 (2009)

3. J. Nordfält, D. Grewal, A. L. Roggeveen, K. Hill, In Review of Marketing Research: Shopper Marketing and the Role of In-Store Marketing 11, 127-46 (2014)

4. A. L. Roggeveen, D. Grewal, C. Townsend, R. Krishnan, Journal of Marketing 79, 3449 (2015)

5. D. Grewal, A. L. Roggeveen, J. Nordfält, Journal of Retailing 93(1), 1-6 (2017)

6. A. Kohli, B. Jaworski, The Journal of Marketing 54(2), 1-18 (1990) DOI: $10.2307 / 1251866$.

7. W. Baker, J. Sinkula, Journal of the Academy of Marketing Science 27(4), 411-427 (1999)

8. R. Hurley, T. Hult, Journal of Marketing 62, 42-54 (1998)

9. N. Lado, A. Maydeu-Olivares, International Marketing Review 18(2), 130-144 (2001)

10. O.S. Kompaniyets, IDO Science 1, 69-72 (2011)

11. I. Krasyuk, T. Kirillova, S. Amakhina, ACM International Conference Proceeding Series (2019) DOI: https://doi.org/10.1145/3372177.3373304

12. B. Lyamin, I. Krasyuk, E. Shepeleva, IBIMA 2019: Education Excellence and Innovation Management through Vision, 9683-9689 (2020)

13. I. Kapustina, T. Pereverzeva, T. Stepanova, I. Rusu, IOP Conference Series: Materials Science and Engineering 012120 (2019) 
14. O. Pirogova, M. Makarevich, O. Ilina, V. Ulanov, IOP Conference Series: Materials Science and Engineering 012129 (2019)

15. S. Bozhuk, N. Krasnostavskaia, T. Maslova, N. Pletneva, IOP Conference Series: Materials Science and Engineering (2019) DOI: https://doi.org/10.1088/1757899X/497/1/012115

16. S. Krymov, V Kolgan M., S. Suvorova, O. Martynenko, IOP Conference Series: Materials Science and Engineering (2019) DOI: https://doi.org/10.1088/1757899X/497/1/012126

17. B. Reformat, Journal of Economics and Management 23(1), 45-53 (2016)

18. Global Powers of Retailing (2019) DOI: https://www2.deloitte.com/ru/ru/pages/consumer-business/articles/global-powers-ofretailing.html

19. T.N. Paramonova, I.N. Popova, Prakticheskiy Marketing 4(206), 20-25 (2014)

20. P.C. Verhoef, P.K. Kannan, J.J. Inman, Journal of Retailing 91(2), 174-181 (2015)

21. V.V. Panyukova, Evolyutsiya roznichnoy torgovli $i$ formirovaniye eye integriruyushchey roli $v$ XXI veke. (Kreativnaya ekonomika, Moscow, 2017)

22. O.U. Yuldasheva, Innovatsii marketingovykh modeley rossiyskikh kompaniy v epokhu didzhital transformatsii (St. Petersburg State University of Economics Press, St. Petersburg, 2018)

23. J.J. Inman, H. Nikolova, Journal of Retailing 93, 7-28 (2017)

24. A. Murillo, M. Pimenta, P. Hilletofth, E. Reitsma, Operations and Supply Chain Management: An International Journal 12(3), 175-185 (2019) DOI: $10.31387 /$ oscm0380241

25. E.T. Bradlow, M. Gangwar, P. Kopalle, S. Voleti, Journal of Retailing 93, 76-96 (2017) 